\title{
The Barriers to Proletarianization: Bolivian Mine Labour, 1826-1918
}

\section{ERICK D. LANGER}

Labour history in Latin America has, to a great degree, followed the models set by the rich historiography in Europe and North America. Other than a justifiable concern with the peculiarities in production for export of primary goods, much of the Latin American historiography suggests that the process of labour formation was rather similar to that of the North Atlantic economies, only lagging behind, as did industrialization in this region of the world. However, this was not the case. The export orientation of the mining industry and its peripheral location in the world economy introduced certain modifications not found in the North Atlantic economies. The vagaries of the mining industry, exacerbated by the severe swings in raw material prices, created conditions which hindered proletarianization and modified the consciousness of the mine workers.'

Mining was in some ways an exceptional activity, but it shows in sharp relief the peculiarities of Latin American economic development and subsequent differences in the process of labour formation. In mining, labour specialization was especially marked and also levels of capitalization were much higher than in agriculture or virtually any other export activity. After all, mining production involved, even in the nineteenth century, a mix of skilled and unskilled labour, extensive supervision, the use of a considerable amount of machinery and production schedules that mimicked industrial processes.

Unfortunately, relatively little scholarly work has been done on the history of Andean mine labour from the nineteenth century until the recent past. There is a long and distinguished series of works on colonial mine labour in Bolivia, since the mines of Potosi and its environs represented some of the most important output of silver in the world and contributed mightily to financing the Spanish imperial enterprise. ${ }^{2}$

\footnotetext{
1 Among recent works, Charles Bergquist has taken seriously the export orientation of Latin American economies and its effects on labour formation. See his Labour in Latin America: Comparative Essays on Chile, Argentina, Venezuela, and Colombia (Stanford, 1986). For a critique of Western-based models of labour formation, see Dipesh Chakrabanty, Rethinking Working.Class History: Bengal 1890-1940 (Princeton, 1989).

2 For colonial mining labour demands, see Peter J. Bakewell, Mfiners of the Red Mountain: Indian Labour in Potosf, 1545-1650 (Albuquerque, 1984); Jeffrey A. Cole, The Potost Mita, 1573-1700: Compulsary Indian Labour in the Andes (Stanford, 1985); Enrique Tandeter, Coercion and Market: Silver Mining in Colonial Potost, 1692-1826, trans. Richard Warren (Albuquerque, 1993); and Ann Zulawski, They Eat From Their Labour: Work and Social Change in Colonial Bolivia (Pittsburgh, 1995).
}

International Review of Social History 41 (1996), pp. 27-51 
However, most of the studies on the colonial period bear little direct relevance to the republican period, since the infamous mita, a type of forced mine labour in which Indian communities in a vast region around the mines participated, ceased to exist after independence. A brief attempt at revival of the mita in the late $1820 \mathrm{~s}$ in the administration of Andrés de Santa Cruz, changed to the "voluntary mita", was ineffective. ${ }^{3}$ Nevertheless, the close connection between agriculture and the mining industry persisted even after the abolition of the mita. The heavily peasant countryside remained the primary labour reserve for the mines until the twentieth century. While mining in many ways was different from other export activities, the reliance on the peasant economy for labour was a general characteristic found throughout many Latin American export economies.

I wish to address three issues that are crucial for understanding the development of mining labour in the nineteenth century: the level of mechanization in the mines and its implications for labour; sources of mine labour in the nineteenth century; and the effects of agrarian rhythms on mine labour supply. Each one of these issues is central to how labour conditions changed in Latin America, especially in the heavily capitalized export sector. Through the examination of these topics I hope to redefine our understanding of mining labour in nineteenth-century Bolivia, as well as help to categorize the changes of labour in Latin America in general.

There are three basic problems with the still developing historiography on Bolivian mining. First, the emphasis has been on the largest and most efficient mining companies, distorting our understanding of the levels of mechanization and labour control in the vast majority of the mines. The take-over of the Bolivian mining industry by a new, export-oriented elite was a pattern common throughout Latin America in the second half of the nineteenth century. Whether it be coffee growers in Central America, cattle ranchers of the Argentine pampas, or cotton farmers of the northern Peruvian coast, an influx of foreign capital, a change in government policies towards laissez-faire liberalism, and the willingness of the new elites to supply raw materials to the burgeoning and industrializing North Atlantic economies, made possible a vast transformation in production and, thus, in the relations of production. In the case of Bolivia, the new mining elite in the second half of the nineteenth century went beyond reforming the mining sector to reorganize rural property relations as well. This became possible as mine renovations and the finding of new, productive silver veins brought about a boom lasting from the 1860 s into the 1890 s. The silver miners gained

3 Antonio Mitre, Los patriarcas de la plata: Estructura socioeconómica de la minerfa boliviana en el siglo XIX (Lima, 1981), pp. 141-142.

- For one of the latest additions to this vast literature, see for example Victor BulmerThomas, The Economic History of Latin America Since Independence (Cambridge, 1994). 


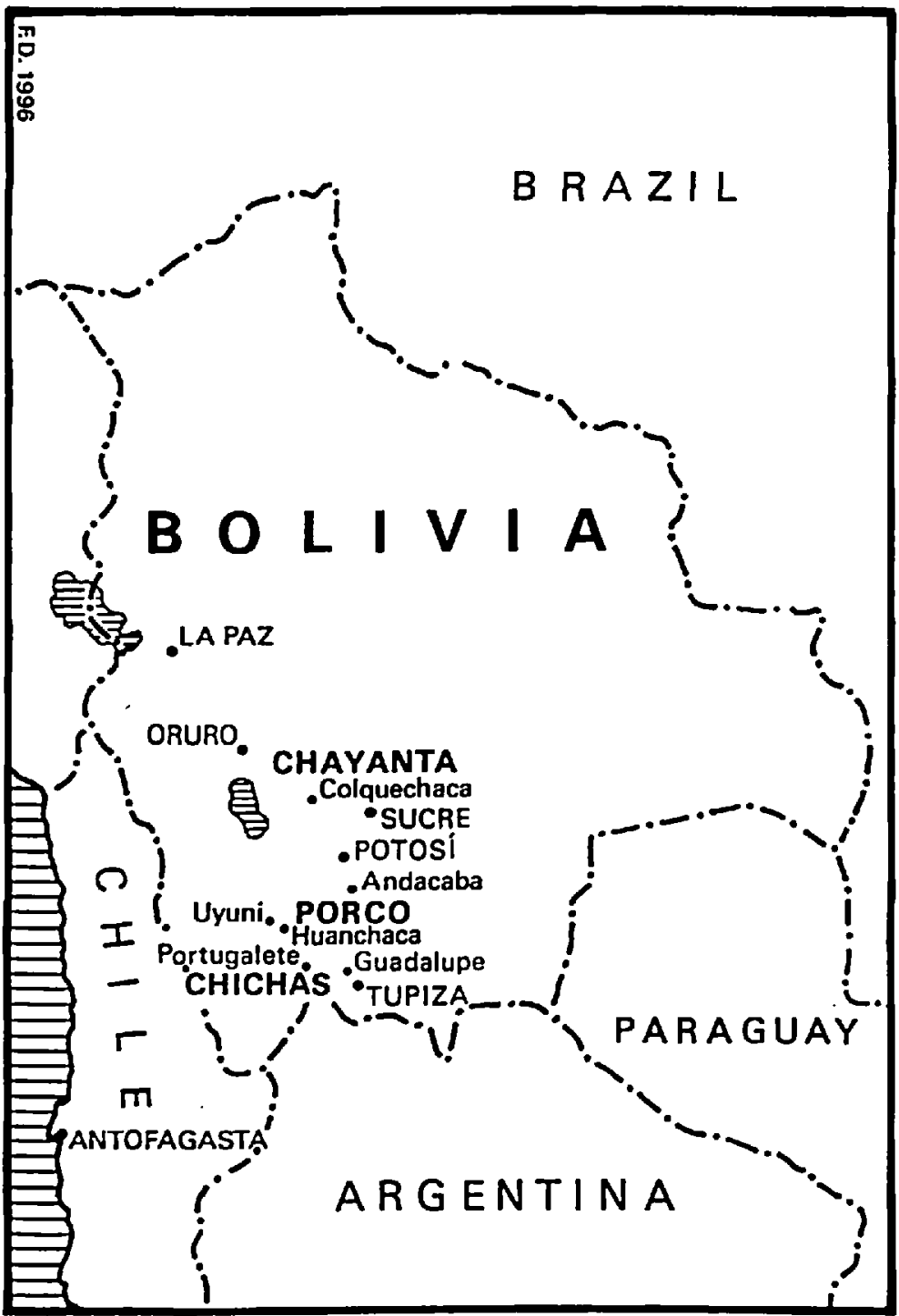

Figure 1. Bolivia

political ascendancy by the 1860 s, taking over direct political control of the country by the 1880 s. One of the most important efforts was the abolition of the Indian communities and the effort to settle frontier lands, an effort to bring market forces into the countryside and make it more responsive to the demands of the mining economy.

3 The idea that the abolition of Indian communities, what one scholar has called the "First Agrarian Reform", was part of a liberal-inspired plan to foster development of the mining export sector and was first developed by Tristan Platt in Estado boliviano y ayllu 
One of the distinguishing features of the mining boom in the late nineteenth century throughout Latin America was its high level of mechanization. This was the case in certain mining firms in Bolivia as well, especially as the price of silver began to drop towards the latter part of the century. A principal reason for high silver output in Bolivia in the second half of the nineteenth century was that new owners, with the aid of Chilean and British capital, invested heavily in new machinery, modern transportation networks and production processes. An influx of mining engineers, many from Germany, accelerated this process of modernization. Thus, the German Francke brothers created a new refinement process which improved the amount of mineral recuperated from the ore. Later, the Franckes would become partners in one of the most successful mining companies in Bolivia, Aramayo, Francke and Company, based in Tupiza, in southern Bolivia. ${ }^{6}$

This process of increasing mechanization, while especially marked in the mining industry, was not unique to it. Throughout the nineteenth century Chilean agriculture, for example, was highly mechanized, with Chilean estate owners enamoured with the new machines purchased in Britain and other European countries. Likewise, the purchase of steam engines for the Tucuman sugar refineries in Argentina revolutionized the industry, bringing about a lengthy boom period in sugar production. In Mexico, silver and copper mining also increased, with heavy US investments.

While the new technology was a vast improvement over the colonial methods, the new historiography has overemphasized the modernization of mining technology in the nineteenth century. This is certainly the case for Bolivia. Recently, Tristan Platt has shown that there was a mining boomlet reaching its peak around 1840 in the ancient colonial mines around the city of Potosí. According to Platt, innovations in technology, especially in the processing of ores, made this possible. ${ }^{8}$

andino: Tierra y tributo en el Norte de Potost (Lima, 1982). Its extension to frontier lands is discussed in Erick D. Langer, Economic Change and Rural Resistance in Southern Bolivia, 1880-1930 (Stanford, 1989), pp. 21-22.

- For an overview of this modernization, see Mitre, Los patriarcas, pp. 90-108, 112-137; also Gustavo Rodriguez Ostria, El socavon y el sindicato: Ensayos historicos sobre los trabajadores mineros siglos $X I X \cdot X X$ (La Paz, 1991), pp. 36. The Franckes' specific contributions are discussed in Ramiro Condarco Morales, Aniceto Arce: Artifice de la extensión de la revolucion industrial en Bolivia (La Paz, 1985), pp. 265-268.

${ }^{7}$ For Chile, see Gabriel Salazar Vergara, Labradores, peones y proletarios: Formacion y crisis de la sociedad popular chilena del siglo XIX, 2nd ed. (Santiago, 1989), pp. 156172; for Tucumán see Daniel J. Santamarfa, Azticar y sociedad en el Noroeste argentino (Buenos Aires, 1986), pp. 9-22; for Mexico, see for example Mark Wasserman, Capitalists, Caciques, and Revolution: The Native Elite and Foreign Enterprise in Chihuahua, Mexico, 1854-1911 (Chapel Hill, 1984), pp. 71-94.

- Mitre, Los patriarcas. For the Potosf mining boomlet, see Tristan Platt, "Produccion, tecnología y trabajo en la Rivera de Potosí durante la república temprana", Paper presented at the Encuentro Internacional de Historia "El siglo XIX, Bolivia y América Latina", Sucre, 25-29 July 1994. 
Platt's study in certain ways is characteristic of the studies on mining, where an emphasis on the industry leaders (a significant but small minority of companies) preponderates. Because of Antonio Mitre's pathbreaking study, many have taken the Huanchaca Company, the largest and best-capitalized mining company in nineteenth-century Bolivia, as the model with which to understand silver mining in Bolivia at that time. Huanchaca was the exception rather than the rule. While the company might have produced a large portion of the total silver in late nineteenth-century Bolivia (according to one estimate about 46 per cent of all silver exported in 1882), ${ }^{9}$ in terms of technology and thus in the number of labourers employed, it was hardly a typical mining operation. The emphasis on mining technology innovation, which was a relatively exceptional behaviour, also bedevils other studies eager to show Bolivia's technological capabilities in the nineteenth century. ${ }^{10}$

Another problem in studies of Latin American export industries is the emphasis on large enterprises (often foreign-run), because they were efficient enough to leave historians copious documentation. This has distorted our understanding of export industries in general, for the export sectors often consisted of medium or small companies as well. Some might have fitted into the interstices of the export economy, as Florencia Mallon has shown for the mining region of the Central Highlands of Peru, whereas others, such as the coffee estates in Central America, were often run by smallholders."

It is also necessary to take into account regional variations, for they have proved very important. Witness, for example, Friedrich Katz's seminal article on the regional variations of Mexican labour, in which he showed that wages, debt peonage arrangements and labour supply diverged greatly, based on degrees of coercion, competition for labour among different sectors, as well as types of economic development. ${ }^{12}$ For Bolivia, mining labour regimes also have a regional dimension. In terms of labour access, it is possible to distinguish four types of mining operations. ${ }^{13}$ One was the mining centre located in the high altiplano

\footnotetext{
- Emesto Ruck, "Bolivia: Su producción actual de plata en 1882, segun cálculo del suscrito", Colección Ruck 541, p. 4, Archivo Nacional de Bolivia [hereinafter ANB].

${ }^{10}$ Mitre, Los patriarcas. Condarco Morales's study, Aniceto Arce, does likewise.

"Florencia Mallon, The Defense of Community in Peru's Central Highlands: Peasant Struggle and Capitalist Transition, 1860-1940 (Princeton, 1983); William Roseberry, Lowell Gudmundson and Mario Samper Kutschbach (eds), Coffee, Society, and Power in Latin America (Baltimore, 1995).

12 Friedrich Katz, "Labour Conditions on Haciendas in Porfirian Mexico: Some Trends and Tendencies", Hispanic American Historical Review, 54:1 (1974), pp. 1-47.

13 As far as I know, there is no serious study of mining in northern Bolivia (in the La Paz district) for the nineteenth century except for Gustavo Rodriguez Ostria, "Vida, trabajo y luchas sociales de los mineros de la serranía Corocoro-Chacarilla". Historia y Cultura, 9 (1986), pp. 151-167. This region might provide a different model of labour access about which we have no knowledge at present.
} 
or in extremely high altitudes, where agriculture was non-existent and the Indian communities that surrounded the mines were sparsely populated and consisted essentially of herders. This was the case with the Huanchaca Company, positioned in one of the most infertile regions of the high altiplano. The Huanchaca Company has been taken as the model of nineteenth-century silver mining because of the superb study by Antonio Mitre. ${ }^{14}$ The second type of mining operation, about which most of the writing on colonial mining has focused, was located near large urban centres founded in colonial times to service these mining districts. The important mining centres were located adjacent to the cities of Potosi and Oruro. The third type, most studied in northern Potosí department (Chayanta), was the mining district located close to Indian communities whose numerous members worked largely in cultivating fields of the high valleys. The fourth type, prevalent in southern Potosí provinces, such as Chichas and Porco, incorporated mines with nearby haciendas. Access to labour and different types of labour available in the different regions determined to a large extent the amount of mechanization of the silver mines, the degree of self-sufficiency of the mines (and thus their costs), as well as the relationship between the countryside and the mining centres. (For a table of all mining companies mentioned, their owners and their relative locations, see Appendix, p. 51.)

Most studies have focused on either the heavily indigenous northern Potosí districts or the altiplano type such as the Huanchaca Company. This ignores the southern Bolivian type of mining-agricultural complex, which indeed was in many ways more representative of Latin American export industries. After all, vertical integration, diversity in production, the maintenance of a large labour reserve, were all characteristics of many Latin American export sectors, especially if one takes into account smaller enterprises. In the south, the most important mining enterprises functioned in conjunction with the surrounding countryside, often firmly in the hands of the mining company itself. As we shall see, the problems of labour access (recruited primarily from the peasants on the surrounding haciendas) and of supplying the mines with foodstuffs, fuel and other goods were very different from those mines that were not integrated into an agricultural enterprise. ${ }^{15}$

The third basic problem of the historiography is the idea of progress in the labour force, from poorly organized part-time miner-peasant to a fully conscious proletarianized labour force that, by the mid-twentieth

\footnotetext{
"Mitre, Los patriarcas.

is Only Ramiro Condarco Morales, in his voluminous study of the silver oligarch and Bolivian president Aniceto Arce, notes this type of mixed agricultural-mining enterprise, but does not follow up on the implications for the operation of the mines located within the agricultural estate. See his Aniceto Arce, pp. 597-598. Curiously, Condarco discusses the "ecosymbiosis" of Arce's haciendas, but fails to take into account Arce's southem mining possessions. Instead, like Mitre, he concentrates on the Huanchaca Company, an atypical mining enterprise as noted above.
} 
century, constituted one of the most radical and powerful labour movements in the world. While Guillermo Lora, the Trotskyist labour historian, most fully represents this trend, others have borrowed the ideas of labour development from E.P. Thompson and Eric Hobsbawm to create a similar progression. This is the case with Gustavo Rodriguez Ostria, who, while rejecting many of Lora's ideas about the weak political development of nineteenth-century miners, still accepts the idea that there was a type of linear development of labour relations from the paternalistic nineteenth century to the tin mining regimes in the early twentieth century under which the Bolivian labour movement became fully politicized. ${ }^{16}$ However, recent studies have questioned this progression. Tristan Platt, for example, has shown how mine workers in the late twentieth century continue to worship earth deities, called the tio (uncle) in the mines. Offerings to the tro, such as cigarettes, coca leaves, and other ritually charged objects are placed at shrines within the mine shafts, to receive permission to take the earth's bounty. These offerings take place within a context of a highly capitalized enterprise where, presumably, the workers themselves are ideologically committed to the historical materialism of a Trotskyist strain. ${ }^{17}$ As Dipesh Chakrabarty has posited, the use of European models often does not fit realities in other parts of the world. While the development of labour consciousness in Bolivia has some similarities to the European case, the class consciousness of the Andean miners melded with strains of powerful religious beliefs far predating this class consciousness. ${ }^{18}$

Given these problems in the historiography, let us now look in greater detail at the issues of capitalization and mechanization, access to labour, and agrarian rhythms with a sensitivity to the four regional variations about which we know in nineteenth-century Bolivia.

\section{Labour and the mechanization of mines}

Mechanization is often a response to labour scarcity. In Latin America, this has not usually been the case. Instead, employers tried to tie workers

16 Guillermo Lora, A History of the Bolivian Labour Movement, 1848-1971, trans. Christine Whitehead (Cambridge, 1977); E.P. Thompson, The Making of the English Working Class (London, 1966); Eric Hobsbawm and George Rudé, Captain Swing: A Social History of the Great English Agricultural Uprising of 1830 (New York, 1975); Rodriguez Ostria, El socavon.

${ }^{17}$ Tristan Platt, “Conciencia andina y conciencia proletaria: Qhuyaruna y ayllu en el Norte de Potos:", HISLA: Revista latinoamericana de historia economica y social, 2 (1983), pp. 47-73. Platt argues that the to represents old Andean deities rather than what Michael T. Taussig, in The Devil and Commodity Fetishism in South America (Chapel Hill, 1979), described as a representation of the devil, which for the workers meant a symbol of their own capitalist exploitation. See also June Nash, We Eat the Mines and the Mines Eat Us: Dependency and Exploitation in the Bolivian Tin Mines (New York, 1979).

${ }^{18}$ Dipesh Chakrabarty, "Postcoloniality and the Artifice of History: Who Speaks for Indian Pasts?", Representations, 37 (1992), pp. 1-26. 
to their enterprises through debt or coercive measures, ignoring the modernization of machinery as a solution to this dilemma. ${ }^{19}$ Mechanization occurred primarily in activities directly tied to exports, such as mining. Unlike agrarian estates or textile mills, mining enterprises in Latin America had to compete in the world market and remain as efficient as possible. Thus, levels of mechanization remained relatively high, as recent research on mining has shown. ${ }^{20}$

Much has been made of the introduction of machinery in Bolivian mines, as well as the extension of the transportation revolution, through the building of railways, in the second half of the nineteenth century. ${ }^{21}$ The impact of railways, however, was more limited than might appear at first glance. The principal beneficiary of the railway between Antofagasta on the Pacific coast and the Bolivian highlands was the Huanchaca Company and its impact was relatively late. It reached Oruro in 1892, just as the silver mining boom reached its close with the financial crisis engendered by the bankruptcy of the Bank of Potosi and the rapid fall of international silver prices. Moreover, the vast majority of silver mines were at no time close enough to the rail lines to benefit effectively from the new transportation network. ${ }^{2}$

This meant that most mining operations depended upon the timehonoured method of moving their products by llama or by mule, both the ore from the mine to the grinding and refining mills, as well as the refined mineral to the coast or, in the last few years of the silver era, to the railhead in Uyuni. As one observer noted in 1908, "[j]ust as in earlier times, the transport of minerals from these mines is done exclusively by llamas or mules, which constitutes a great inconvenience for the miners". ${ }^{23}$ Moreover, the mines depended upon animal transport to supply them with important inputs into the mining operations, such as salt, wood, foodstuffs and fuel. Tristan Platt has shown how in the 1840 s the mines in the south-western corner of the country (in the first type of region, the high altiplano), depended upon the Indian community members of Lipez province to transport with their extensive llama herds the minerals and supplies such as salt and fuel required by

\footnotetext{
19 There is a vast literature on this topic for rural estates in Latin America. See for example Magnus Morner, "The Spanish-American Hacienda: A Survey of Recent Research and Debate", Hispanic American Historical Review, 53:2 (1973), pp. 183-216 and Eric Van Young, "Mexican Rural History since Chevalier: The Historiography of the Colonial Hacienda", Latin American Research Review, 18:3 (1983), pp. 5-61. For obrajes, the textile mills, see for example Alberto Flores Galindo, Arequipa y el sur andino, siglos $X V I I I-X X$ (Lima, 1997), pp. 36-44.

30 Mitre, Los patriarcas; also see Manuel Contreras, Tecnologfa moderna en los Andes: Minerta $e$ ingenierta en el siglo XX (La Paz, 1994) and Alberto Flores Galindo, Los mineros de la Cerro de Pasco, 1900-1930 (Lima, 1974).

"II See especially Mitre, Los patriarcas and Condarco, Aniceto Arce.

2 See Langer, Economic Change, pp. 25-29.

23 William van Brabant, La Bolivie (Paris, 1908), pp. 272.
} 
the mines. ${ }^{24}$ Transportation costs were a high proportion of total mining costs, and the number of individuals employed in this task was relatively large. In the case of the Guadalupe Company, the third largest silver mining company in the country, in 1888 just the cost of taking the ore from the mine head to the refining plants, the ingenios nearby, cost 27.57 Bolivianos [Bs] per box [cajon] of metal, or about 10 per cent, out of a total of $292.06 \mathrm{Bs}$ per box in total expenses. While some authors have made much about the fact that mine owners introduced carts to bring the ore to the ingenio, freeing themselves from the expense of the llama drivers, this does not appear to have been the case here. That year, the Guadalupe Company paid llama drivers 17,398 Bs for their services, while expending 4,806 Bs for the carts and draft animals. ${ }^{25}$

These costs did not include the transportation of the silver to the rail line that at this time was approaching Uyuni. Once the railhead arrived in the altiplano town, all mine owners other than those of the Huanchaca Company still had to hire pack animals to take the metal bars to the railway. This entailed significant costs as well as a large number of pack animals. Only the Colquechaca Company, the largest mining operation in northern Potosi, in 1890 needed 2,000 to 3,000 llamas monthly to transport its metals to Uyuni. This was a large number of pack animals, if one multiplies that several times to include the demands of the smaller companies that proliferated throughout the region. Although in some cases the companies employed mules which could take a larger burden, competition for the pack animals and the greater expense of mules over llamas made the companies prefer the latter animals over the former. ${ }^{26}$

In addition to problems with utilizing the railways, mechanization lagged in significant aspects in most mining enterprises. Few Bolivian

24 Tristan Platt, "Calendarios tributarios e intervención mercantil. La articulación estacional de los ayllus de Lipez con el mercado minero potosino (siglo XIX)", in Olivia Harris, Brooke Larson and Enrique Tandeter (eds), La participación indigena en los mercados surandinos: Estrategias y reproduccion social. Siglos XVI a XX, (La Paz, 1987) pp. 502516.

${ }^{25}$ Compañía Guadalupe de Bolivia, Memoria presentada a la Junta General de Accionistas (Sucre, 1889), pp. 12, 10, Be 162, XIII, Biblioteca Nacional de Bolivia [hereinafter BNB]. For the argument that carts diminished the dependence on llama drivers, see Gustavo Rodriguez Ostria, "Los mineros: Su proceso de formación (1825-1927)", Hisloria y Cultura, 15 (1989), p. 89 and Rodríguez Ostria, El socavón, p. 36.

${ }^{26}$ For the needs of Colquechaca Company, consult Lucio Leiton to Jacobo Aillon, Potosf, 15 January 1890, "Copiador Cartas Abel Vacaflores 1889. Libro No. 2", Fondo Vacaflores, Archivo de la Sociedad Agricola, Ganadera é Industrial de Cinti (La Paz) lhereinafter FV]. I have estimated that a llama can carry one quintal, or about 100 pounds. For competition over pack animals, see Leiton to Justino H. Balderrama, Potosf, 21 January 1890; Leiton to Guillermo Leiton, Potosf, 25 February 1890; Leiton to Balderrama, 25 February 1890, ibid. The use of llamas and mules and the cost of the latter is documented in Leiton to Nestor Villa, 29 January 1890; Leiton to Sr Prsdte de la Ca Aullagas, 1. February 1890; and Leiton to G. Leiton, 18 March 1890, all ibid. 
mining companies actually had the wherewithal to adopt new machinery into the productive process other than the most highly capitalized, but exceptional companies studied most intensively by scholars. In addition to the Huanchaca Company, the Colquechaca and Guadalupe companies attained a certain level of mechanization. Whereas the Guadalupe company owned five steam motors with a combined power of $120 \mathrm{hp}$ in 1889 (two of which were out of service), this was an unusually well-mechanized operation. $^{27}$

Moreover, the records at our disposal often make historians concentrate on only a particular phase of mining production in which mechanization was most likely. ${ }^{28}$ The long period of exploration for a productive vein, during which the company employed the most primitive type of technology, has been largely ignored. Exploration in the nineteenth century entailed getting men to hack away at the earth with pickaxes, with the occasional use of black powder and later, dynamite. If the records of Compañía Consolidada de Colquechaca (a smaller successor to the Colquechaca Company discussed above) from the early twentieth century might be used to indicate nineteenth-century patterns, independent contractors performed much of the exploration work. These independent contractors owned few tools - they often borrowed the mining companies' shovels, picks and wheelbarrows - and took part of their pay in the ore they came across while digging the shaft. This was the case with the Andacaba Company as well, where in 1887 the administrator hired four Italian contractors to dig the shafts to the main vein of silver ore. This payment in kind was similar to the kajcha arrangements in the colonial period, where workers took the richest ore to supplement their meagre wages. In other words, at least in the exploration phase, when mine owners had little or no income to offset expenses, colonialtype relations continued to persist in nineteenth-century mining. ${ }^{29}$

2 Compaña Guadalupe de Bolivia, Memoria (1889), pp. 12-13. Gabriel Salazar makes a similar point for Chilean mining operations. See his Labradores, pp. 214-216.

All studies thus far for the nineteenth century are almost exclusively based on the mining companies' annual reports. There are several problems with this type of source. First of all, the annual reports, printed in neat folios and often with extensive ornamentation, privilege those companies that were wealthiest and most highly capitalized. Reports come into existence usually only when significant progress had already been made and the company produced some kind of ore. Secondly, the company reports, which were not only reports to stockholders but also pieces of propaganda to lure new investors, as in stock reports today, tended to emphasize the high technology employed and the successes. Only with the weekly reports written by the mine administrators to company headquarters is it possible to get a real sense of how these companies worked.

2 For a revealing look at issues facing a mining company in the exploration phase, see "Cartas Copiadores, Cía Colquechaca, Sep. 30, 1907 a Nov. 1913". For example, in September 1912 the company paid 865 Bs to contractors and only 266.90 Bs for wages. Only 9 Bs were used for materials, out of a total of $1147.80 \mathrm{Bs}$ total expenditures. See ff. 546-547. For the Andacaba Company, see Libro No. 3, f. 87, Fondo Aniceto Arce, 
In contrast to the heavily capitalized Huanchaca Company, the administrator's reports show a different picture for the much smaller Andacaba operation, certainly more typical of nineteenth-century mining operations than the former. At the height of mining activity, between 29 October and 4 November 1888, the Andacaba Company employed 80 individuals working on four different shafts. In addition to the administrator and his servant, a blacksmith and five carpenters, the company employed 28 barreteros, miners who dug into the walls and extracted the ore, nine peons and nine palliras, women who broke up and sorted the ore according to its quality. To transport the ore from the depths of the mine to the surface was the task of six carreros, men who handled the animal-driven carts, as well as 20 chasquiris, who stood in line to hand sacks of mineral or perhaps water buckets to drain the mine from one to the next. Soon afterwards, the company added a contingent of torneros, by March 1889 eighteen men, who were responsible for turning a large wheel in the mine rigged to pull sacks of mineral or buckets of water out of the mine shafts. By March 1890, the height of production with 125 labourers ( 40 of whom were barreteros), the lack of machinery was even more noticeable. Only three carreros were left, while the number of men pumping increased and those carrying buckets jumped to $35 .{ }^{30}$ The distribution of jobs, which shows the high proportion of men occupied in the backbreaking labour of simply hauling bags of ore, pumping water by hand, or carrying buckets of water, shows the lack of mechanization in a mine owned by one of the most forward-looking miners of the silver era.

Labour remained by far the largest expenditure for most mining companies. Typical in this respect are the accounts for Andacaba in July 1888 when the company spent $617.29 \mathrm{Bs}$ on materials, whereas 1,256.76 Bs went on labour. ${ }^{31}$ In other words, mining costs broke down to 67 per cent for labour and only 33 per cent for materials. In Guadalupe, where, as noted above, operations were relatively mechanized, in 1889 labour costs constituted 87 per cent of the costs of producing silver. By 1895 the Guadalupe had reduced the percentage attributable to labour down to 43 per cent. ${ }^{32}$ This was in stark contrast to mining costs in the Huanchaca Company, where according to Antonio Mitre labour

ANB [hereinafter FAA]. For an excellent treatment of nineteenth-century kajchas, see Gustavo Rodriguez Ostria, "Kajchas, trapicheros y ladrones de mineral", Siglo XIX: Revista de Historia, 8 (1989), pp. 125-139.

${ }^{30}$ See Libro No. 3, ff. 227, 261, 371, FAA. For definitions of the various occupations, see Frédrique Langue and Carmen Salazar-Soler, Diccionario de términos mineros para la América española (siglos XVI-XIX) (Paris, 1993).

${ }^{31}$ Libro No. 3, ff. 192, 196, FAA.

32 Compañla Guadalupe de Bolivia, Memoria (1889), p. 11; Memoria presentada a la Junta General de Accionistas (Sucre, 1896), p. 45, Bd 253, BNB. 
represented 23 per cent of total costs for extracting the ore from the mine in Pulacayo. ${ }^{33}$

Similar patterns existed throughout Latin America, as in the second half of the nineteenth century increasing mechanization brought down labour costs. Virtually all activities, and especially agriculture, saw employers cutting labour costs. In the case of Chile, mechanization in the countryside was accompanied by a shift from permanent labourers to hiring mostly day labourers. This also led to an increasing number of peons migrating to the mines in the north of the country, where low wages created high mobility rates among workers too. ${ }^{34}$

\section{Access to labour}

Providing enough labourers for working the mines had been a problem since colonial times. The colonial state utilized forced labour recruited from a wide swath of the Andes, though there were important exceptions, such as the flourishing silver mines in Oruro, just north of Potosi. ${ }^{35}$ In the republican period it proved impossible to reinstitute the mita, and thus miners had to try different methods. First, much of the silver produced came not from production by the owners, but by independent contractors, called kajchas, whose activities frequently shaded into outright robbery of ores. ${ }^{36}$ In 1827 kajchas contributed about half of all output; by 1850 these contractors still provided a third of all silver production. Kajcha production tapered off in the following decades, only to arise again very briefly in the last few years of the nineteenth century when silver mining entered into crisis before being replaced by tin. ${ }^{37}$

The use of independent contractors (and thus the possibility of mineral theft) was virtually inevitable, however, given the demands of the initial phases of mining production. In the exploration phase of the mining process, when mine owners nervously analysed the earth they cut through for signs of ore, the administrators kept costs as low as possible and hired as few men as possible. As soon as a vein tapered off into less valuable minerals, they again laid off workers to conserve resources. This was the case with the Andacaba operation, where in April 1887 the mine occupied only 30 workers to cut a shaft to the principal vein and clean out air ducts (chimineas). Where metal was found in the chimineas, a few palliris - seven out of the total - sorted out the best

33 Mitre, Los patriarcas, p. 154. With such a divergence in figures, it is likely that Mitre's calculations factor in additional costs which the other records do not reveal, but still the difference must have been significant.

34 Salazar, Labradores, pp. 216-219.

is Zulawski, They Eat from the Mines.

36 Rodriguez Ostria, "Kajchas, trapicheros"; also see Mitre, Los patriarcas, pp. 138-145.

"Ibid., p. 145; Rodriguez Ostria, "Kajchas, trapicheros"; idem, El socavon, Pp. 47-49. 
pieces for processing. In contrast, by May 1890 the mine was producing in full swing, employing over a hundred workers, with fourteen palliris. ${ }^{38}$

It is necessary to distinguish between short-term swings in labour demand and supply as well as long-term trends, such as the increase in labour supply in the second half of the nineteenth century. Regional variations and differential levels of capitalization must be taken into account too. The highly capitalized Huanchaca Company hired fewer labourers because of mechanization, especially since the surrounding countryside was largely devoid of human habitation. In turn, the late nineteenth-century growth of towns in the northern Potosi mining district made it less necessary to depend on the surrounding Indian communities whose economy remained resolutely oriented towards agrarian subsistence. Nevertheless, during the nineteenth and even early twentieth centuries the distinction between town and country was not that great, for town residents usually had their own plots of land somewhere or worked that of their extended families. After all, the vagaries of the mining cycle might at any time bring about the loss of their job; keeping their options open by returning to the fields when jobs disappeared could keep their families alive. Only in the mining regions next to a major city such as Potosi or Oruro was it possible to survive in an urban occupation while waiting for the mines to hire again. Perhaps more importantly, the cyclical nature of international mineral prices and Bolivia's dependence on international economic forces forced the mine labour force not to proletarianize completely lest they starve when the mines went into cyclical decline.

Not only mine labourers, but many important mining companies also tried to hedge their bets when playing in the export market, where they had no real control over prices. One important way was to combine landed estates with mines. This was a common strategy throughout Latin America, where vertical integration took some of the risks out of a poorly developed infrastructure. For example, Warren Dean, in his book on the industrialization of São Paulo, shows how large enterprises engaged in these kinds of practices. ${ }^{39}$ The largest mining enterprise in southern Bolivia, the Guadalupe Mining Company, used such an approach. It owned the haciendas of Oploca and Salo to the north of Tupiza, a silver refinery in Guadalupe, and mines in nearby Tatasi, Chocaya and Guadalupe. Altogether, the company owned almost 25,000 square miles of land, most of it rocky and mountainous, but with some prime agricultural lands suitable for growing fodder and other crops tucked into the lower valleys. In 1892 the estates of Oploca and Salo had 2,915 peons living on the land, of which 987 were adult men and 947 were adult women. These peons owned 17,966 llamas and 4,384

38 Libro No. 3, ff. 9, 459, FAA.

${ }^{39}$ Warren Dean, The Industrialization of São Paulo, 1880-1945 (Austin, 1969). 
donkeys for transporting ore, salt, fodder and fuel for the company. ${ }^{40}$ It was a combination that Aniceto Arce, principal shareholder of Huanchaca and one of the most progressive silver miners, utilized, purchasing the estates that had made up the old Condado de Oploca, a vast landholding in southern Bolivia. Arce's friend and political rival, Gregorio Pacheco, in the 1880s purchased Arce's stock to become the largest shareholder in this agro-mining enterprise. Aniceto Arce apparently did not abandon the model of combining agricultural estates with mining, because in 1889 he used the peons from his newly purchased hacienda of La Lava (south of Potosi city) to work in the silver mines of his Andacaba Company. ${ }^{41}$ It is likely that other mining concerns also attached agricultural estates to their companies at the end of the nineteenth century, but our lack of knowledge about the workings of the vast majority of nineteenth-century mining companies prevents us from quantifying this trend.

There were many advantages to combining large landholdings with mining enterprises. The haciendas produced income from agriculture that were independent of the vagaries of the mining cycle, and thus propped up the mining portion in times of low production. This was the case for the Guadalupe Company, which in 1888 lost 74,371.04 Bs in mining operations. In turn, the haciendas attached to Guadalupe Company earned $36,486.99$ Bs which, combined with other earnings, diminished total losses to 28,525.22 Bs. Earnings from the haciendas came primarily from the sale of fodder crops and rents paid by the hacienda peons for their plots. The company also used many of the products produced on demesne lands for the mines, such as a portion of the fodder, as well as to stock the company stores with foodstuffs. ${ }^{42}$

The estates also provided the mine owners with other services from the landholdings' large service tenantry. All estates in highland Bolivia (as well as elsewhere in the Andes) maintained a peonage arrangement in which resident workers were obligated to pay for their access to lands through a combination of rental payments in cash, in kind (such as providing wood for fuel, a small portion of their livestock, eggs, etc.), as well as a certain number of days of labour and transportation of

- Compaña Guadalupe de Bolivia, Memoria (1889). Guadalupe was the third largest silver mining company in the country in the late nineteenth century. See Ruck, "Bolivia", Colección Rack 541, p. 4, BNB. For descriptions of the Guadalupe estates, see Companifa Guadalupe de Bolivia, Estadustica general de las propiedades de la Compañfa Guadalpue de Bolivia (Sucre, 1892), Bd 338, XI, BNB; and William L. Schurz, Bolivia: A Commercial and Industrial Handbook (Washington, DC, 1921), p. 131.

4 Arce's purchase of Oploca is documented in Condareo, Aniceto Arce, pp. 597-598. By 1889, Gregorio Pacheco was the majority stockholder, with 2,000 out of 3,000 shares, whereas Arce had no stock at all in the company. See Companifa Guadalupe de Bolivia, Memoria (1889), p. 2. References to the use of peons from Hacienda La Lava first appear in Eduardo Vallalba to Jose Ma. Goitia, 19 July 1889, Libro No. 3, f. 283, FAA.

- Compaña Guadalupe de Bolivia, Memoria (1889), pp. 10, 13, 14. 
crops to market, for which the landlord had to pay at stipulated, but usually below-market rates. ${ }^{43}$

The mining companies that owned haciendas changed labour obligations from working on the farm to the mines. The haciendas, in essence, presented vast and inexpensive labour reserves for the mining enterprises in boom times. Thus, owning haciendas was advantageous to mining enterprises because the mining company could keep its workers from year to year, but without having to pay them extra during the low points of the mining cycle. After all, the hacienda provided the workers with land (for which they paid rent, another source of income) and absorbed labourers who became relatively skilled at their mining jobs. These workers were theoretically always available, unlike the floating population of the mining towns, where labourers drifted from one mining boom to the next. In the case of the Guadalupe Company, the peons from Hacienda Oploca performed virtually all types of tasks in the mines, from the relatively unskilled jobs of llama drivers, ore carriers, suppliers of fuel to the ovens (leñadores), and ore mixers in the mills (mortiris), to the more specialized jobs of ore cutters (barreteros) and oven operators (horneros). For Andacaba, the recent addition of Hacienda La Lava's "Indians" (indios), as they were invariably described, for the period for which we have records, did not permit them to be used other than in the most unskilled jobs, such as ore and water carriers, water pumpers and llama drivers. ${ }^{44}$ According to Gregorio Pacheco, administrator of Guadalupe in the last decades of the nineteenth century, using peons as miners also had the advantage that the remuneration they received "facilitates the payment of their rents". ${ }^{\text {is }}$ As a result, the mining companies recouped part of their labour costs through the rental payments the peons had to make to the company for the usufruct of its land.

Moreover, the wages in the mines and the earnings from transporting minerals must have had a profound effect on the economy of the hacienda peons. The sums that this employment pumped into the peasant economy were significant, at times much larger than the rents the peons

\footnotetext{
"For a discussion of the hacienda labour system in nineteenth-century Bolivia, see Langer, Economic Change, pp. 54-61.

${ }^{4}$ Gregorio Pacheco, Compañia Guadalupe de Bolivia: Informe que el Delegado del Directorio de dicha compaña presenta d la Junta General de Accionistas (Sucre, 1889), p. 7, Be 156, VII, BNB. For Andacaba, see Libro No. 3, ff. 283-434, FAA. Unfortunately, we do not know the percentage of hacienda peons who worked in Guadalupe's mines and refining establishments. The Andacaba Company records, where the relationship between hacienda and mine was more recent, suggest that the proportion of workers was significant, but did not represent the majority. During the period from 16 March to 27 April 1890 , the only time-span for which we have this type of documentation, an average of 31 out of 97 workers in the Andacaba mines were hacienda peons from La Lava, or about a third of all workers. It is likely that this was a lower percentage than in Guadalupe, where the relationship between the mines and the landed estates was much more ancient.

"Pacheco, Companila Guadalupe de Bolivia, p. 7.
} 
had to pay for the usufruct of hacienda land. For example, while for the Guadalupe Company in 1888 the amount paid out to transport minerals and the amount brought in for rent were roughly equal (17,389 Bs versus 17,590 Bs respectively), in 1896 just for the transport of minerals the company spent $62,643 \mathrm{Bs}$, whereas the total amount of rent charged was only $16,718 \mathrm{Bs}^{46}$ If one includes the money peons earned as mine workers as well, this must have constituted a significant sum that the mining company pumped into the peons' household economies.

Early in the nineteenth century owners paid a high proportion of wages in kind, not in money. In 1826 and 1827 the mine owners of Cochinoca and Aranzazu paid approximately 60 per cent of their wages in goods, presumably recovering some of their costs in this way. ${ }^{47} \mathrm{By}$ the late nineteenth century workers still took goods in lieu of wages, but a much smaller percentage. For the seven accounts we have for the payment of La Lava hacienda peons in early 1890 , on average workers only received 16 per cent of their wages in merchandise rather than cash. ${ }^{48}$ In the case of Guadalupe Company, the administrator in 1888 complained in the annual reports that the company stores were not very well stocked and that they had to buy their merchandise from the nearest city of Tupiza rather than directly from Europe. Nevertheless, he insisted that the store was there to prevent the abusive pricing of outside merchants rather than a means of making more money. ${ }^{49}$

Despite these relatively benevolent practices, labour discipline remained a problem throughout the nineteenth and early twentieth centuries. In part, the blame lay on the hybrid quality of the labour force on these agro-mining enterprises, which was needed both as agriculturists as well as miners. The records of the Andacaba Company show that mine administrators fought continuously to get the number of workers they required from the hacienda. Moreover, many of "the Indians" of La Lava fled when they could, to return to their families and fields. From the beginning, the peons, according to the frustrated Andacaba administrator, left when they felt like it. While they could be charged for the goods they had received from the company store, they did not return to the mines once they had decided to go back to the hacienda. ${ }^{\text {so }}$ At other times, many of the workers sent from La Lava

46 Compañfa Guadalupe de Bolivia, Memoria (1889), pp. 7, 8, 10; Memoria de 1896, pp. 11, 35, 36.

" William Lofstrom, Damaso de Uriburu (La Paz, 1982), 36-37.

4 Libro No. 3, ff. 374-375v, 385-386v, 397v-398, 407-408v, 413-414v, 424-425v, 433-434, FAA.

- Compaña Guadalupe de Bolivia. Memoria (1889), p. 14; Pacheco. Companta Guadalupe de Bolivia, p. 8.

*_Libro No. 3, Emilio Benavidez to José Ma Goitia, Andacaba, 19 July 1889, f. 283, FAA. 
did not show up or showed up a few days late for work. ${ }^{51}$ When they did not receive their socorros (their payment in food and goods), many simply abandoned the mines and returned home. Some simply refused to do the most onerous tasks. This was the case in 1890 , where the administrator could not prevent the rise of water in the shafts "because the Indians working the pumps decided all to get sick".s2

It is possible that the problems in labour discipline were attributable at least in part to Hacienda La Lava's recent integration into the mining regime, but it is likely that at least some of these problems persisted even in the Guadalupe Company and other agro-mining enterprises where integration was long-standing. The reason for the lack of discipline was that it was difficult for the companies to enforce their mine labour demands on the hacienda peons. After all, the peons had their own agrarian base which served as their primary means for subsistence. If they invested in livestock, it made them relatively independent of the demands for mine labour, for they could serve in another valuable function, that of transporting the ores. The companies had little incentive to throw peons off the farms, for in a labour-intensive and poorly capitalized agrarian economy the number of workers on a farm was the primary determinant of the properties' worth. A diminished labour force was also not in the interest of the company, for in the agro-mining complex the hacienda peons had to do double duty, that of mine and agricultural labourers. The Guadalupe Company was aware of these problems, even in the 1890 s purchasing agricultural machinery to lower costs and, not incidentally, make the hacienda workers more available to work off their labour obligations in the mines. ${ }^{53}$ This might have been a successful experiment, but it did not bear fruit as soon afterwards the company ceased production because of the precipitous decline of silver prices in the last years of the nineteenth century.

It is also likely that the mining companies found it very difficult to expand work obligations beyond those that were traditionally required of the peons. As I have shown elsewhere, Andean hacienda workers, in common with many other pre- and proto-industrial workers throughout the world, had an acute sense of what could be required of them and what was customary. In the case of Bolivia and other Andean countries, this was closely tied to the peasants' conceptions of the peculiarly Andean notions of reciprocity. Leadership and legitimacy were tied to the show of redistribution of goods by leaders. Hacienda owners as well as mine owners understood this need to show their largesse, though the creole elites often couched their understanding of reciprocal relations in

\footnotetext{
si See for example Libro No. 3, Indalecio López to Benavidez, Andacaba, 19 and 22 February, and 2 March 1890, ff. 330, 333, 354, FAA.

52 Libro No. 3, Lopez to Benavides, Andacaba, 2 March 1890, f. 354; Lopez to Mauricio Pidot, Andacaba, 21 March 1890, f. 379, FAA.

${ }^{33}$ Compaña Guadalupe de Bolivia, Memoria de 1896, p. 14.
} 
paternalistic terms. During festivals, for example, landlords provided not only food and drink, but also participated in rituals where their workers would come up one by one and kiss the hand of the landlord and present him with a chicken or something similar. In turn, the landlord would provide the worker with a token of his leadership by presenting the latter with a bolt of cloth or perhaps a ready-made shirt. ${ }^{54}$ Given the close ties between countryside and mine on the agro-industrial enterprises, this reciprocal symbolism remained strong in the mines as well. We see the importance of these concepts when the employer did not fulfil his obligations. It is likely that, for example, this sentiment was behind the peons' abandonment of the Andacaba mines in early March 1890 because they did not receive their accustomed socorros..$^{35}$ Custom, such an important ingredient in the daily contestation of power between hacienda owners and their labour force, must have been an important barrier to labour discipline in the agro-mining enterprises.

\section{Agrarian rhythms}

A striking characteristic of mining in Latin America until the late twentieth century was the well-nigh universal seasonal scarcity of mine labour. Indeed, as coercive practices in obtaining mine labour declined after the colonial period, mine owners suffered acutely from the agrarian rhythms imposed by their peasant-based mine labour force. This was the case in Peru, where in the nineteenth century this problem remained a constant complaint. Workers would simply return to their communities when the harvests were ready to pick. Even the mighty Cerro de Pasco Corporation in the Central Highlands, financed by large US mining interests, could not attract workers during certain times of the year in the early twentieth century. ${ }^{56}$

Complaints from mine administrators about the seasonal lack of labour were well-nigh universal in nineteenth-century Bolivia as well. Dámaso de Uriburu, an Argentine mining entrepreneur, had problems of this kind in 1826. One knowledgeable contemporary observer blamed the lack of work in the mines in the mid-1840s on the disappearance of the professional mine labourers during the chaos of the independence wars. The same problem continued, however, throughout the nineteenth cen-

\footnotetext{
s4 For a discussion of labour relations in southem Bolivian haciendas, see Erick D. Langer, "Labour Strikes and Reciprocity on Chuquisaca Haciendas", Hispanic American Historical Review, 65:2 (1985), pp. 255-277.

ss Libro No. 3, Lopez to Benavides, Andacaba, 2 March 1890, f. 354, FAA.

so For nineteenth-century Peru, see Carlos Contreras, Mineros y campesinos en los Andes: Mercado laboural y economla campesina en la Sierra Central siglo XIX (Lima, 1987). For an intriguing study of this problem for Cerro de Pasco, see Elizabeth Dore, "Social Relations and the Barriers to Economic Growth: The Case of the Peruvian Mining Indüstry", Nova Americana, 1 (1978), pp. 245-267.
} 
tury. In 1895, a few generations later, Gregorio Pacheco complained that his mines were not working "because of the harvests, workers are not to be found". ${ }^{37}$ In addition, as Gustavo Rodríguez Ostria has written extensively, miners were frequently absent during festivals such as carnival and other such celebrations. The correspondence from the Andacaba mines corroborates this impression. During carnival in 1890 the administrator reduced the mine labour force to a skeleton crew of eight to ten workers, but to only those "worthy of confidence". This proved necessary after the company suffered through various drunken fights, one outright dismissal of a mine worker, and putting labourers to work in the mines very late in their shifts, after they had slept off their hangovers. Even in the early twentieth century the vast Uncía and Llallagua mining complexes in Chayanta virtually shut down during the week of All Saint's Day because the workers simply left to celebrate in their home towns. ${ }^{\text {s8 }}$

Of course, the agricultural and festival cycles did not just impinge upon work in the interior of the mines. During certain seasons, pack animals owned by community members were also not available, because the Indians were on their yearly migrations to the lowlands, to exchange salt and other highland products for maize in the valleys. ${ }^{59}$ Even professional muledrivers were often agriculturists on the side and simply disappeared during the sowing and harvest seasons, though at times it was possible to compensate for the lack of Indian-owned llamas by contracting mestizo owners of donkeys to transport the ore. ${ }^{60}$

Regional differences were very important. Mining companies close to cities had little problem with seasonality. The documentation available for the Real Socavon de Potosí Company, with its mines in the huge mountain that towered over the city of Potosí and had given life to it, never mentions a seasonal lack of labour. ${ }^{61}$ In turn, mining regions far from large urban centres, such as those in Chayanta or Chichas, had a serious problem with mine workers wandering off to their homesteads during the harvest season. This was especially the case with small

7 Lofstrom, Dámaso de Uriburu; Pacheco quote in Rodríguez Ostria, El socavon, p. 31. For the 1840s, see José Maria Dalence, Bosquejo estadístico de Bolivia (La Paz, 1975 [1848]), pp. 259-260.

is Rodrguez Ostria, El socavon, pp. 27-29. For Andacaba, see Libro No. 3, Lopez to Benavidez, Andacaba, 6 February 1890, f. 313; López to Jerardo Azurduy, 7 February 1890 , f. 315; Lopez to Benavidez, 8 February 1890, f. 318; López to Benavidez, 9 February 1890, f. 321, FAA. For All Saint's Day, see Zacarias Ponce to German Zelada, Colquechaca, 26 October 1907, f. 10, "Cartas Copiadores Cia Colquechaca, Sep. 30, 1907 a Nov. 1913". Archivo Gimenez (Sucre) [hereinafter AG].

39 Platt, "Calendarios tributarios".

"Lucio Leiton to Guillermo Leiton, Potosf, 18 March 1890, "Copiador de Cartas Abel Vacaflores 1889: Libro No. 2", pp. 491-492, FV.

61 See the company's various Informes, stretching from 1860 to 1877 , preserved in MSS Rlick, Minas, Cía Bolívar, Potosí 1820-1840, BNB. 
companies, where the insecurity of mining and the subsequent swings in the number of employees made it necessary for mine labourers to have access to fields so that they could survive when the inevitable lay-offs occurred. The small companies, with their small capital, also were most vulnerable to the swings in the prices of minerals.

While a few large-scale mining companies such as the Huanchaca Company, with their large and stable mining production were probably not as affected by seasonal labour fluctuations, the hacienda-mining complexes were extremely vulnerable to this type of problem. Indeed, the contradictory needs of mining and agriculture formed the greatest weakness of these types of enterprises. The problem of seasonality bedevilled even the largest agro-mining enterprise, the Guadalupe Company. For example, Gregorio Pacheco noted in 1889 that "there are seasons, such as those for sowing and harvest, in which there is a scarcity of [mine] workers, given that they are the same arrenderos (hacienda peons) who cannot stop attending to agricultural work". ${ }^{62}$

In addition, these agro-mining enterprises suffered from contradictory capital investment demands in an effort to attenuate the seasonal labour shortages. The Guadalupe Company attempted to introduce agricultural machinery on its lands as a means to free up peon labour for the mines, but the mining complex also demanded large amounts of capital for the upkeep of machinery and the introduction of new labour-saving technology. Thus, in 1889 Gregorio Pacheco prohibited any capital improvements in the company's haciendas, permitting only those expenditures "absolutely necessary for the preservation" of the farms. ${ }^{63}$ By 1896 the company had, however, invested in a new dam and irrigation canals, as well as a Whitman pressing machine for fodder, and some harvesters for the alfalfa crop despite losing almost $150,000 \mathrm{Bs}$ in mining operations. ${ }^{64}$ The investment in agriculture rather than using the money to switch over to tin mining possibly brought the company to the verge of bankruptcy, for shortly thereafter it was purchased by Chilean interests and the headquarters moved to Santiago, Chile. ${ }^{65}$ Thus, efforts to provide a more consistently available labour force were not always successful, given the conflicting demands for capital between agricultural and mining enterprises.

Problems with seasonal labour scarcity continued well into the twentieth century, showing that the process of proletarianization had not finished in the mines even in very fundamental aspects. Records are scarce for the period before World War I and little has been written about labour conditions in the crucial transitional period from silver to

\footnotetext{
2 Pacheco, Comparila Guadalupe de Bolivia, p. 7.

w Ibid., p. 10. Emphasis in the original.

at Compañfa Guadalupe de Bolivia, Memoria de 1896, pp. 14, 12.

os Schurz, Bolivia, pp. 130-131.
} 
tin between 1895 and $1918 .{ }^{66}$ Even in northern Potosí, the region where labour union development and proletarianization of the labour force was presumably the highest, seasonality was very important. The records of the Consolidada Company of Colquechaca for the period between 1907 and 1918, in the northern Potosí region, help us to fill this gap. The company was one of the last and best hopes of the post-silver boom Sucre elites to compete with the new multinational corporations that were beginning to dominate the tin mining industry. ${ }^{67}$

The image presented by the Consolidada Company during this time is very different from the image we have of tin companies after World War I. The Consolidada Company operated primarily with independent contractors rather than hiring its own workers as a means of keeping down expenses. Theft in the mines was endemic, indicating that many independent or perhaps occasional miners existed and that a market for contraband ores continued to exist. Indeed, in 1907 the administrator admitted that the contractors worked more with the kajchas, or mine thieves, than with the company, causing serious losses. At other times contractors switched between kajcha and contracting, depending on what mines were accessible. ${ }^{68}$

The problem with labour discipline and keeping workers from disappearing during fiestas and other unofficial holidays was one of the company's major problems and did not change appreciably over the period for which we have records. In late October 1907 the administrator suspended work in the mines because "I don't try to fool myself that I can have work done next week until after All Saint's Day". He also reported that the large mining centres in Uncia and Llallagua had shut down as well. ${ }^{69}$ In early 1908 workers again disappeared before carnival

so See for example Rodriguez Ostria, El socavon, the best recent mine labour history, which jumps from the late nineteenth century to 1918. Likewise, Antonio Mitre, Bajo un cielo de estaño: Fulgor y. ocaso del metal en Bolivia (La Paz, 1993) largely skips over this period. The only important contribution is Manuel E. Contreras C., "Mano de obra en la minerfa estanffera de principios de siglo, 1900-1925", Historia y Cultura, 8 (1985), pp. 97-134.

${ }^{67}$ I am extremely grateful to Pilar Gimenez Dominguez, who made these records available to me. For an overview of the Sucre elite's attempts to get into the tin mining industry, see Langer, Economic Change, pp. 46-47. Most studies on Bolivian mine labour have focused on northem Potosf. For a representative sample, see Olivia Harris and Javier Albó, Monteras y guardatojos: Campesinos y mineros en el norte de Potosi, rev. ed. (La Paz, 1986); Nash, We Eat the Mines; Platt, "Conciencia andina"; Godoy, Mfining and Agriculture.

64 The records indicate that independent contractors composed the vast majority of the labour force, especially in the rubrics of exploration and shaft digging, the most labourintensive activities. Unfortunately, the letters only record relations with the general contractors rather than with the individual labourers, making it impossible to determine the composition of the contractors' workforce. For kajchas, see Ponce to Zelada, 29 February 1907, f. 59; 2 May 1908, f. 87, "Cartas Copiadores Cía Colquechaca, Sep. 30, 1907 a Nov. 1913", AG.

${ }^{\circ}$ Ponce to Zelada, 26 October 1907, f. 10, "Cartas", AG. 
and were not expected to return until well into March. In April workers were scarce because of Easter celebrations. In June the Corpus Christi festival seriously restricted exploration activities, while in September the people of the village of Aullagas tore down the wooden gates to the mines to use as firewood for the feast of Saint Michael. ${ }^{\text {x }}$

Over a decade later similar problems persisted. A new administrator warned the company's directorate that there were "many difficulties that one encounters in this place, such as the scarcity of working people in certain seasons". ${ }^{71}$ In April of that year "work has been paralyzed during all the days of Holy Week and Easter", and "there is a complete scarcity of muledrivers, which is why the delivery of our products has been totally paralyzed". Only in mid-May did the labour shortage due to the feast days disappear. Whereas in 1912 the administrator could boast that "despite the inconveniences because of the [August 6th] patriotic holidays of the past week, I have succeeded in making our contractors work without any stoppage", in 1918 for the 6 August national holidays workers had not reappeared by 8 August. Again, in late October "because of the feasts of All Saint's Day, there has been a loss of five to six days of work in all sections of the company". 72

Festivals were not the only worries of the company, for workers continued to disappear during the harvest season as well. In April 1908 "the scarcity of people continues $[\ldots]$ because they have begun to go to the countryside for the harvest". By June even the barreteros, the most specialized and highly paid mine workers, quit en masse to go to work in the cornfields of the valleys. ${ }^{33}$ In April 1913 the administrator tried to increase wages and keep the workers in the mines to finish their labour contracts by force instead of going to the harvest, but by early May the miners had disappeared to harvest their crops anyway. A month later most workers reappeared, but only after having completed the harvest. ${ }^{74}$ In 1918 "day by day our production diminishes because of the lack of workers $[\ldots]$ this is occurring in all sections $[\ldots]$ because all are retiring to the countryside [for the harvest]". ${ }^{75}$

Increasingly, however, complaints centred on competition between various mining enterprises for workers, leading to a rise in wages or

T0 Ponce to Zelada, 21 March 1908, f. 73; 11 April 1908, f. 80; 20 June 1908, f. 114; 12 September 1908, f. 140, "Cartas", AG.

"Francisco Leaño to Directorio, n/d, f. 2, "Letters", AG.

7 Leaño to Zelada, Colquechaca, 4 April 1918, f. 41; 25 April 1918, f. 71; 16 May 1918, f. 103, "Letters"; Ponce to Zelada, Colquechaca, 12 August 1912, "Cartas"; Leaño to Zelada, La Gallofa, 8 August 1918, f. 231; Armando Seoane and Leaño to Zelada, La Gallofa, 31 October 1918, f. 344, "Letters", AG.

" Ponce to Zelada, Colquechaca, 25 April 1908, f. 85; 13 June 1908, f. 112, "Cartas", AG.

74 Leaño to Zelada, Colquechaca, 21 April 1913, f. 696; 5 May 1913, f. 711; 2 June 1913, "Cartas", AG.

75 Leaño to Zelada, Colquechaca, 18 April 1918, f. 61, "Letters", AG. 
contractors' fees throughout the region. In April 1918 a new mining company took away workers by raising wages. ${ }^{76}$ Competition was even more marked for pack animals. In northern Potosí, where mining companies were among the most heavily capitalized in the country in the twentieth century, the vast majority of transporters of minerals continued to be members of the numerous Indian communities of northern Potosí and the altiplano around Lake Poopó in Oruro. This continued to bring problems, for in July 1918 most Indians had disappeared into the valleys with their llamas, in their age-old voyage to trade salt and folk medicines for lowland maize. Mine owners had complained about the same problem seventy years before, prior to the advent of the railways. ${ }^{n}$ While competition brought about higher transport prices, even the stimulus of increased profits could not always move the Indians to change their traditional activities. In September and October 1918 the company sent agents to the towns of Macha and Pocoata to offer high payments to transport goods from the railhead at Challapata to the mines and take tin bars in return, but did not get any takers. Presumably, the llamas had recently returned from their trip into the valleys and their owners preferred to have them rest rather than returning to the road. ${ }^{78}$

Transportation bottlenecks remained an important problem for much of Bolivian mining. Miners had to rely heavily on Indian community members for transporting their ore and other goods. Only in the 1930s, with the construction of vehicle roads and the widespread introduction of trucks, did reliance on Indian peasants for transportation diminish. ${ }^{7}$ Within the mining enterprises the proletarianization of workers proceeded somewhat more rapidly. During World War I and especially in the 1920s the tin industry consolidated into a small number of companies that dominated the country's mining until the Bolivian Revolution of 1952. Although the top three companies were presumably owned by Bolivian nationals, in fact they relied very heavily on foreign capital and acted as multinational firms in ways that the silver mining companies had not. ${ }^{80}$ The high levels of capitalization, possible through the participation of important US, French, British and Chilean interests, created a situation in which new transportation methods and mechanization brought about great changes in labour conditions. The migration of Cochabamba peasants to the northern Potosi mines largely severed the

\footnotetext{
76 Leaño to Zelada, Colquechaca, 11 April 1918, f. 54, "Letters", AG. Also see Contreras, "Mano de obra".

"Leaño to Zelada, Colquechaca, 4 July 1918, f. 185, "Letters", AG. For patterns in the 1840 s, see Platt, "Calendarios tributarios".

"Seoane to Zelada, La Gallofa Colquechaca, 26 September 1918, ff. 298-299; Leaño to Zelada, La Gallofa, October 17 1918, f. 321, "Letters", AG.

"For a detailed discussion of the transportation problem, see Mitre, Bajo un cielo, pp. 72-102.

so Ibid., pp. 202-213.
} 
links between the surrounding countryside and mines that had existed previously. What remained was an Andean consciousness, expressed in the belief of underground deities that controlled access to mining riches in the shafts. ${ }^{81}$

However, one must take into account regional differences even here. Indeed, scholarly attention on the northern Potosi case has been so great because the largest firm, Patiño Enterprises, had its largest mines there and because labour union activity first surged in the Uncia-Llallagua sector. Unfortunately, we do not have much information on the fate of the great agro-mining complexes, but it is highly likely that labour relations were rather different there. Although a Chilean syndicate purchased the Guadalupe Company in 1907, the presence of peasantminers living on the company's estates must have retarded proletarianization in ways that were not possible in northern Potosí. Suggestive of the persistence of the combination of peasant and miner is a recent characterization of the mine worker of Chichas (where the Guadalupe Company is located), in which the author asserted that

the miner of Chichas works occasionally in the mines when there is no work in his fields, for this [reason] especially in the sowing season he abandons the work of the mines to sow, although he only has a tiny plot of land, sufficient to take part in the huackes' [a sowing festival particular to Chichas]. The authentic miner is from Potosi or Oruro who does not leave his work all year around; they are poorer than those who alternate [mine] labour with agricultural tasks, these [latter] have maize, potatoes, meat, etc. ${ }^{22}$

\section{Conclusion}

The case of Bolivian mining labour, while unique in certain respects, helps us to understand better the changes and continuities in labour relations throughout Latin America. Although the mining sector was relatively heavily capitalized and mechanized (especially compared to agricultural enterprises), the development of labour consciousness did not follow European patterns. This was due in large part to migration by mine labourers to the agricultural sector and back into mining, depending on job possibilities and seasonal labour demands. Other than the very exceptional Huanchaca Company, more heavily capitalized and mechanized than any other mining syndicate and located in the desolate reaches of the altiplano, few companies succeeded in proletarianizing the labour force. Indeed, certain Andean rituals and concepts from the agrarian sector were important in keeping the mine labour force content as well. Belief in and propitiation of the tio, an ancient deity of the

11 Nash, We Eat the Mines; Taussig, The Devil.

- Francisco Salazar Tejerina, Leyendas y tradiciones de Tupiza, 2nd ed. (La Paz, 1981), p. 12 . 
underworld, also shows the penetration of Andean concepts despite the workers' apparently "modern" political beliefs.

Not only were workers exposed to deproletarianization due to the vagaries of a particular mining enterprise, but the vulnerability to the swings of the international price regime made it prudent to cultivate ties to the countryside. Even large mining companies such as the Guadalupe Company recognized this problem when they combined mining concerns with agricultural enterprises. Virtually unstudied and relatively common in the important southern mining districts, these enterprises shifted from agriculture to mining and vice versa as prices varied. Likewise, hacienda peons became mine labourers and then went back to their fields after their turn to work in the shafts. Not only did this hinder the development of a class consciousness, but brought about severe labour discipline problems. Nevertheless, this was a rational means of dealing with the intractable problem of the swings in the mining economy. As shown above, these problems were not unique to the Bolivian mining sector. In fact, examining how workers in peripheral regions such as Latin America hedged their bets as they tried to protect themselves from the brutal realities of the global market-place will bring about new insights into the process of labour formation in much of the rest of the world.

\section{Appendix}

Regions, mining companies and mine owners mentioned in the text

\begin{tabular}{|c|c|c|}
\hline Region (and towns) & Mining company & Principal owner \\
\hline $\begin{array}{l}\text { Northern Potosf (dep.) } \\
\text { (Uncia, Llallagua, } \\
\text { Colquechaca) }\end{array}$ & $\begin{array}{l}\text { Colquechaca Company } \\
\text { Consolidada Gallofa de } \\
\text { Colquechaca Company }\end{array}$ & $\begin{array}{l}\text { Jacobo Aillon } \\
\text { Various (Sucre elites) }\end{array}$ \\
\hline High altiplano & Huanchaca Company & Aniceto Arce \\
\hline $\begin{array}{l}\text { Near cities } \\
\text { (Oruro, Potosf) }\end{array}$ & Real Socavon de Potosf & Avelino Aramayo \\
\hline $\begin{array}{l}\text { Agro-mining enterprises } \\
\text { (Tupiza, Portugalete } \\
\text { - Chicas Province) } \\
\text { (Porco Province) }\end{array}$ & $\begin{array}{l}\text { Guadalupe Company } \\
\text { (Haciendas Oploca, Salo) } \\
\text { Andacaba Company } \\
\text { (Hacienda La Lava) }\end{array}$ & $\begin{array}{l}\text { Gregorio Pacheco } \\
\text { (initially Aniceto Arce) } \\
\text { Aniceto Arce }\end{array}$ \\
\hline
\end{tabular}

